2. Part of epiphyseal cartilage of upper vertebra shown in I. Long columns of cartilage cells, indicating the intense activity of the cartilage, are evident. $\times 130$.

3. Part of epiphyseal cartilage of lower vertebra shown in 1 . Cartilage columns are shorter than those in 2 , indicating less marked activity of the growth cartilage. $\times 130$.

4. Sagittal section of lumbar vertebrae of mature rabbit showing persistence of epiphyseal cartilage in upper vertebra. This figure demonstrates that the more active epiphyseal cartilage in a bone tends to persist longer. The lower end of a vertebral body in most pronogrades is the 'growing' end. $\times$ Io.

5. Section of upper end of femur of newborn child. The ends of most long bones before ossification are nourished by vessels running in cartilage canals. Some of the vessels pass from the diaphysis into the cartilaginous end and an example of this is seen in this figure. The cartilage is in the upper part of the figure and the diaphysis of the bone towards the lower part. $\times 86$.

\title{
Bone as a Mineral Reserve
}

\section{By E. C. Owen, The Hannah Dairy Research Institute, Kirkhill, Ayr}

Bone gives its possessor biochemical as well as structural advantages. Bone is not a dead tissue and the calcium and phosphorus which give it its hardness are also labile, if need be as a source of nourishment for the softer more actively metabolizing tissues of the body. Ca deficiency in wild animals should be a rare phenomenon. P, however, is much harder to come by. Fishes living on the continental shelves of the various land masses acquire $\mathbf{P}$ by eating small arthropods and algae. The small plants and animals of the phyto- and zoöplankton keep the phosphate wastes from the land masses in biological circulation. The fate of $\mathrm{P}$ has, in the past, been to pass from the fish to the birds which prey on them and so to be deposited on oceanic islands as guano. Rock phosphate deposits, on which modern agriculture, and therefore human nutrition, largely depend, are chiefly fossilized guano. Two very large deposits of apatite, one in the Kola Peninsula, the other in Canada, are exceptions in being igneous in origin. As every farmer knows $\mathrm{P}$ is dearer than he would like it to be. $\mathrm{Ca}$, on the other hand, is literally 'dirt cheap'. It is perhaps therefore not surprising that $\mathrm{P}$ deficiency is still a hazard of both plant growth and animal production.

It is a fact of history that all the newer countries had difficulty in raising cattle. The reason was a mystery until Theiler (1919) (cf. Theiler \& Green, I93 I-2) working in South Africa, showed that the difficulty was due to aphosphorosis. This discovery, together with similar work elsewhere in the world, gave the needed impetus to the superphosphate industry which converts rock phosphate to a form more readily available to plant roots. Nevertheless, for human and farm animal alike, aphosphorosis is still an ever-present hazard. However, if children can get plenty of milk, there is little need to worry about their intake either of $\mathrm{Ca}$ or of P. Drinking half a pint of cow's milk per day makes an adult safe from aphosphorosis. An expectant or nursing mother ought to have twice as much. Herring, if well cooked, provide not only both $\mathrm{Ca}$ and $\mathrm{P}$ in the bones, which one eats, but also vitamin $\mathrm{D}$ in the body oil. Though it is to be admitted that low-Ca rickets certainly exists (Skill \& Kay, I934), we still do not know if rickets in children and its counterpart, osteomalacia, in later life are primarily due to a deficiency in $\mathrm{Ca}$ or in $\mathrm{P}$. From animal experiments, such 
conditions could be due to deficiency of either or of both or to an excess of either. Human dietary surveys, backed by an estimation of balances, could decide this point (Owen, Irving \& Lyall, 1940). Perhaps the reported effects of sodium phosphate in increasing physical endurance are really due to the disclosure of a partial deficiency of phosphate and of a low level of labile $P$ in the bones. During the course of evolution one can imagine that a well-mineralized skeleton of true bone proved better than cartilage in that a bony skeleton resisted bending, and was superior to a framework of calcium carbonate since bone is more resistant to fracture, and is superior to both these since true bone is a labile substance serving as a $P$ bank from which drafts may be made in times of shortage. Overdrafts will eventually break the bank and cause rickets in infants and osteomalacia or osteoporosis in adults. Such overdrafts may be rendered necessary by a winter-time shortage of $P$ or they may be due to some physiological stress such as pregnancy, lactation, egg laying or even rapid growth on food deficient in bone-forming minerals but adequate in other respects. All these stresses have been demonstrated in well-controlled experiments with laboratory animals (Fairbanks \& Mitchell, 1936; Conner, Kao \& Sherman, I941; Zucker \& Zucker, 1946; Doyle \& Porter, 195I). The clinical literature abounds in records of unfortunate patients who have failed, for dietary or hormonal reasons, to surmount the hazards to the skeleton that result from pregnancy, lactation or growth on diets deficient in minerals (Hunter, 1930a-c; Alwens, 1919; Dalyell \& Chick, 1921; Hume \& Nirenstein, I92 I; Park, 1923; Hess \& Unger, 1918; Owen et al. 1940; Gaunt \& Irving, 1939).

There is plenty of evidence in the scientific literature for the hypothesis that, in the metabolism of vertebrates, especially during growth, there is competition between the skeleton and the actively metabolizing soft tissues for dietary $\mathrm{Ca}$ and $\mathrm{P}$ (Fairbanks \& Mitchell, 1936; Zucker \& Zucker, 1946; Doyle \& Porter, 195 I; Conner et al. 194I). There seems to be similar competition for dietary magnesium (Duckworth, Godden $\&$ Warnock, 1940; Duckworth \& Godden, I94I, 1943). Rapid growth is accompanied by poor skeletal mineralization and vice versa.

In this competition the soft tissues are more successful so that, when $\mathrm{Ca}$ or $\mathrm{P}$ or $\mathrm{Mg}$ is supplied by the diet in insufficient amount, or when some other substance in the food, or some pathological or experimental condition, interferes with absorption, the soft tissues take priority over the bones for the supply of these minerals. In a growing animal the result is a poorly mineralized skeleton (Zucker \& Zucker, 1946) with denuded trabeculae in the long bones (Hunter, I930a-c). In this competition the organic matrix of the bone acts like the other soft tissues (Zucker \& Zucker, 1946). If the stress continues long enough rickets may result in the growing animal. In the adult body osteomalacia, osteoporosis (Dalyell \& Chick, I921) or osteitis fibrosa cystica (Hunter, x $93 \circ a-c$ ) may be the result. Hazards that demineralize the adult skeleton are deficient diets (Dalyell \& Chick, 192I), especially if accompanied by frequent pregnancies as in the Chinese women studied by Maxwell (1935), idiopathic steatorrhoea, hyperparathyroidism or exophthalmic goitre (Hunter, I930a-c). Frequent resort to such purgatives as magnesium sulphate (Meulengracht, 1938) or the ingestion of fat of too high a melting-point (Chanda, 1949) deplete the mineral content of the skeleton. In all these instances the soft tissues draw minerals from the 
skeletal stores until the bones are dangerously depleted. A danger signal may be given by attacks of tetany (Dalyell \& Chick, I92I) due to the lowering of the amount of ionized $\mathrm{Ca}$ in the blood when the demineralization is acute. Another warning is the bending or fracture of a long bone. Older people tend often to take diets poor in bone-forming elements (Owen, et al. 1940). Grauhan \& Schulz (1939) showed, that the incidence of fractures increases with age. Hume \& Nirenstein (1921) found that the incidence of osteomalacia in time of war increased markedly with age. Even a normal physiological process may be a hazard. It is generally agreed that the intake of $\mathrm{Ca}$, of $\mathrm{P}$ and of vitamin $\mathrm{D}$ should be increased during pregnancy and lactation. During pregnancy a woman on an adequate diet stores as much $\mathrm{Ca}$ and $\mathrm{P}$ in her skeleton as she does in the foetus and adnexa (Hummel, Sternberger, Hunscher \& Macy, 1936). When the baby is born and she feeds it at the breast these stores are rapidly transferred to the milk. So great is the avidity of the mammary gland for $\mathrm{Ca}$ and $\mathrm{P}$ that a negative balance of $\mathrm{Ca}$ is regarded as normal in early lactation and cannot be made positive by dietary means. Evidently the rapidly metabolizing mammary gland, like the muscles, can successfully compete with the bones for $\mathbf{P}$ and $\mathrm{Ca}$.

In the lactating cow, subjected to thyroxine treatment, the mobilization of $\mathrm{Ca}$ and $\mathrm{P}$ from the bones is so fast that all the $\mathrm{Ca}$ in the milk can come from the bones and, at the same time, the loss of $\mathrm{Ca}$ in the faeces exceeds the total intake of $\mathrm{Ca}$ (Owen, 1948). Under these conditions the $\mathrm{P}: \mathrm{Ca}$ ratio in the milk increases (Owen, 1948), so that more $\mathrm{Ca}$ will be taken from the bones than is required for milk secretion. This extra $\mathrm{Ca}$ appears in the faeces. In the same experiment Owen (1948) also found that the cows were in positive $\mathrm{P}$ balance all the time and that thyroxine increased the positivity of the $\mathrm{P}$ balance. Thus these cows, in depleting the skeletal stores of $\mathrm{Ca}$ and $\mathrm{P}$ in which the ratio of $\mathrm{Ca}$ to $\mathrm{P}$ is somewhat more than $2: \mathrm{I}$, to make milk of $\mathrm{Ca}: \mathrm{P}$ ratio $\mathrm{I}: \mathrm{I}$, transferred the $\mathrm{P}$ to the milk and threw away the $\mathrm{Ca}$. The reverse state of affairs is found in the hen in heavy lay which has to find a large excess of Ca over $P$ to make the shells of the eggs which are almost pure $\mathrm{CaCO}_{3}$. Such hens draw heavily on their skeletal trabeculae but get from that source more $P$ than is needed to make the egg. The excess $P$ is excreted and such hens are in negative $P$ balance (Tyler, $1948-9,1949-50$ ). Just before coming into lay a hen resembles an expectant mother (Tyler, 1948-9, 1949-50; Hummel et al. 1936) in being able to store Ca and P very efficiently in its skeleton. In this instance also, circulating oestrogen is believed to be the cause of the efficient retention. It is likely (Chanda \& Owen, 1952) that negative balances of $\mathrm{Ca}$ in lactating animals and of $\mathrm{P}$ in laying hens are due to a natural increase of thyroid activity in both these physiological states. Teeth do not seem to participate, even during growth, as actively as bone in the body's commerce in $\mathrm{Ca}, \mathrm{P}$ and $\mathrm{Mg}$. They are therefore protected, to some extent, against hazards to which bone is exposed. This was demonstrated for $\mathrm{Ca}$ and $\mathrm{P}$ by Gaunt $\&$ Irving (1939, 1940-1). Nevertheless, these authors showed, in the same experiments, that rachitogenic diets enhance the predentine width of rats' incisors. Duckworth et al. (1940), Duckworth \& Godden, (1940-1, I94I, I943) and Irving (1940) showed that Mg behaved in similar fashion.

Thus, to some extent, maintenance of the composition of the bones and maintenance of the composition of the soft tissues are in conflict. Diets that have an 
unfavourable $\mathrm{Ca}: \mathrm{P}$ ratio, or too small a content of either or of both of these minerals, may allow growth of the soft tissues to proceed while the bones and, to a much less extent, the teeth are inadequately supplied with minerals. The result is rickets which clinicians often say improves when children are physically ill. This paradox simply means that, in rickets, the soft tissues take priority over the bones for $\mathrm{P}$ and $\mathrm{Ca}$, so that any check to the metabolism of the soft tissues makes $\mathrm{P}$ and $\mathrm{Ca}$ available for the formation of bone.

In rats, rabbits, pigs, cows, dogs and man it has been shown that bone formation and the mineral content of the bones are adversely affected by diets in which the ratio of $\mathrm{Ca}$ to $\mathrm{P}$ is greatly different from unity (Shohl, 1939). Vitamin D induces normal formation of bone and tooth when taken with diets which in its absence would produce rickets. The beneficial action of vitamin D is quite general, and all mammals and birds seem to be able to utilize $\mathrm{Ca}$ and $\mathrm{P}$ more efficiently for bone formation in its presence. When sunshine acts on the skin it is believed that it turns 7-dehydrocholesterol into vitamin $\mathrm{D}_{3}$. This apparently is the only dietary factor that man can produce by his own photosynthesis. There has been much discussion concerning the mode of action of vitamin $\mathrm{D}$ in the body. Experiments with radioactive $\mathrm{Ca}$ and radioactive $\mathrm{P}$ certainly show that one of the chief actions of vitamin $\mathrm{D}$ is to favour the transfer of $P$ from the soft tissues to the bones. This results in retention of $\mathrm{Ca}$ along with the $\mathrm{P}$ (Cohn \& Greenberg, 1939; Gaunt, Griffith \& Irving, 1942; Nordfeldt, 1949; Migicovsky \& Emslie, 1949). Even before the introduction of the radioactive-tracer technique dietary experiments by Shepherd \& Macy (1939) with schoolchildren showed that adding vitamin $\mathrm{D}$ to a diet improved the retention of $\mathrm{Ca}$ but decreased the retention of $\mathrm{S}, \mathrm{N}$ and $\mathrm{P}$, just as would be expected if the action of vitamin $\mathrm{D}$ were to favour bony- as against soft-tissue anabolism.

In children, in dogs and in cats, but not in ruminants, a diet rich in cereals predisposes the animals to rickets in the growing period (Mellanby, 1921, 1925, 1949). Mellanby postulated the presence of a rachitogenic factor in cereals. It is now known that Mellanby's rachitogenic factor is a Ca-Mg salt of phytic acid. Phytic acid is inositol-hexaphosphoric acid, and its fate in the gut is still a matter of controversy (McCance, I949). Vitamin D can counteract the action of phytate (Harrison \& Harrison, 195 ; Singsen, 1948) probably because it increases the efficiency of absorption of that part of the $\mathrm{Ca}$ that is not in combination as calcium phytate. The increased efficiency of absorption is probably an effect secondary to the favouring of bone anabolism by vitamin $\mathrm{D}$.

The hormones of the thyroid and of the parathyroid glands are known to affect the transport of $\mathrm{Ca}$ and $\mathrm{P}$ to and from the bones. The rate of secretion of these hormones by the body may be affected by diet, and the effects of their over- or underproduction are often preventable by dietary means.

In toxic goitre there is a rapid loss of $\mathrm{Ca}$ and $\mathrm{P}$ by the gut, and $\mathrm{Ca}$ balances in such patients may become markedly negative (Hunter, 1930a-c). This condition may be simulated in experimental animals of any species by administration of thyroxine. In this type of goitre dangerous demineralization of the skeleton results unless measures are taken to combat the condition. These measures may be surgical removal of some 
of the thyroid gland or treatment with some such antithyroid drug as methyl- or propylthiouracil.

Rapid demineralization of the skeleton results from overactivity of the parathyroid glands (Hunter, I93०a-c). Patients who for any reason have to have their parathyroid glands removed are subject to attacks of tetany. Anderson \& Lyall ( I939), in Aberdeen, made a very careful study of such tetanies and showed that they can be controlled by increasing the ratio $\mathrm{Ca}: \mathrm{P}$ in the diet, thus confirming the earlier observations made on parathyroidectomized rats by Shelling (1932). Nowadays, dihydrotachysterol, taken by mouth, enables subjects with defective parathyroids to eat normal diets. Tetany in animals, as in human beings, is induced when the ratio of various minerals to one another in the blood is disturbed. Particularly potent causes are reductions in the concentrations of $\mathrm{Ca}$ or of $\mathrm{Mg}$ in the blood.

An interesting compensatory mechanism is found in rickets and in osteomalacia. The parathyroid glands are enlarged and active and so ensure that a level of $\mathrm{Ca}$ in the blood sufficient to prevent tetany takes precedence over an adequately mineralized skeleton. For a deficiency of vitamin D lasting, say, from one summer to the next, such a compensatory action by the parathyroid glands must, in the evolution of vertebrates, have had a great survival value; but in our so-called civilized conditions such deficiency may continue for longer than one winter so that we go on taking drafts from an already depleted $\mathrm{Ca}$ bank till exhaustion of it leaves no protection against attacks of tetany.

Lactose has a favourable effect on $\mathrm{Ca}$ retention but other carbohydrates are neutral in this respect. The effect may be due to the fermentation of lactose to lactic acid in the gut, for many organic acids occurring naturally in food, e.g. citric acid and tartaric acid, favour $\mathrm{Ca}$ retention on diets that, in their absence, might produce rickets. Citric acid is a normal constituent of body fluids and, according to evidence quoted by Best $\&$ Taylor (1950), its secretion in the urine parallels that of $\mathrm{Ca}$. Oxalic acid, which occurs in rhubarb and spinach, interferes with $\mathrm{Ca}$ absorption, as it precipitates $\mathrm{Ca}$ in the gut as the very insoluble calcium oxalate (Schmidt-Nielsen \& Schmidt-Nielsen, 1944).

If an animal is changed from a diet poor in $\mathrm{Ca}$ and $\mathrm{P}$ to one rich in these elements, its $\mathrm{Ca}$ and $\mathrm{P}$ balances will become markedly positive (Rottensten, 1938). Even the aged human skeleton, depleted by years of low mineral intake, can store these minerals readily if the patient is given a suitable diet. Adams, Boothby \& Snell (1935-6) demonstrated these effects in elderly subjects. The findings of Owen et al. (1940) lend support to the theory of Fairbanks \& Mitchell (I936) that human Ca balances indicate the degree of depletion of skeletal stores. They showed that the positive $\mathrm{Ca}$ balances of some old people were linear functions of the $\mathrm{Ca}$ intake. Other aged patients did not show this phenomenon. Presumably the latter were in $\mathrm{Ca}$ equilibrium. The experiments of Owen et al. (1940) showed that these different types of elderly people could be as readily distinguished by their $\mathrm{Ca}$ balances as by their $\mathrm{P}$ balances (Figs. I and 2). This is only to be expected if the real cause of variation from person to person is the initial degree of depletion of the skeleton. In a person with a fully mineralized skeleton, over four-fifths of his $\mathrm{P}$ and $99 \%$ of his $\mathrm{Ca}$ are in his bones (Shohl, 1939). Fairbanks \& Mitchell (1936) suggest that subjects under test should have their $\mathrm{Ca}$ and $\mathrm{P}$ stores 
filled by dietary treatment before determining their $\mathrm{Ca}$ and $\mathrm{P}$ requirements. This is important in view of findings by Orr \& Clark (1930) that the greater the monetary income the greater is the $\mathrm{Ca}$ intake.

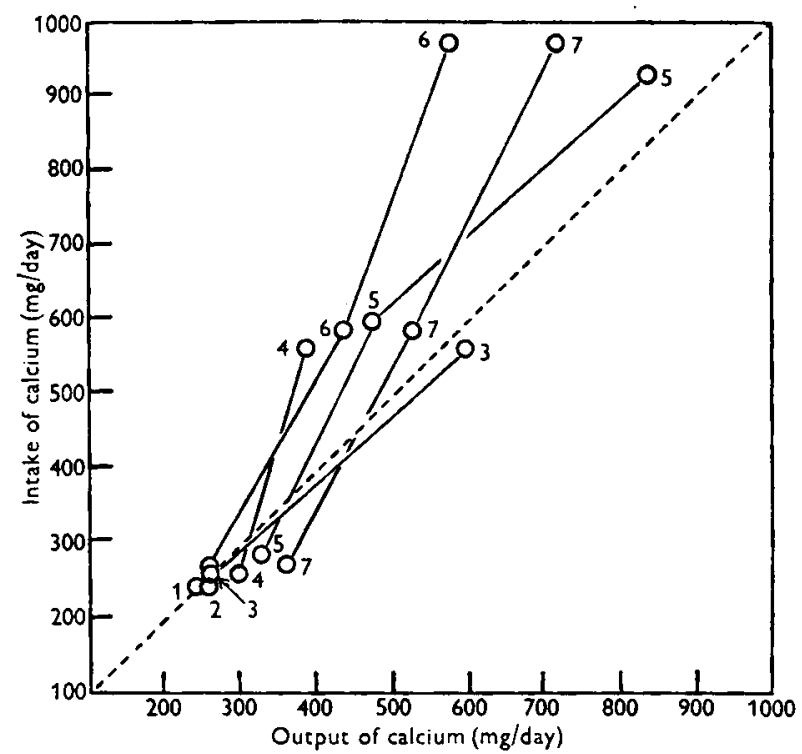

Fig. I. Calcium balances of elderly men (from Owen, Irving \& Lyall, 1940).

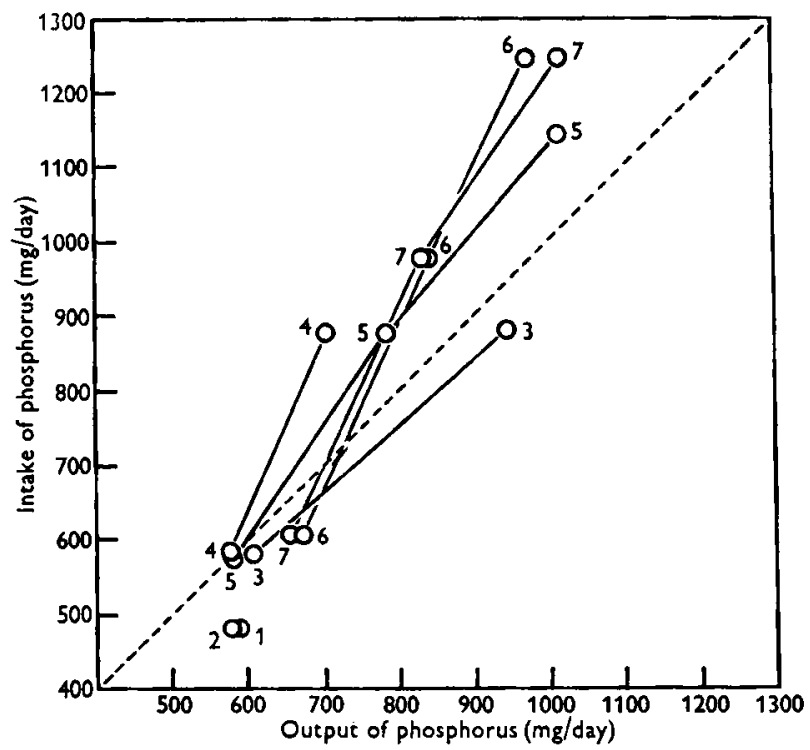

Fig. 2. Phosphorus balances of elderly men (from Owen, Irving \& Lyall, I940).

A certain optimum content of fat in the diet is favourable to the storage of $\mathrm{Ca}$ and $\mathrm{P}$ in bones, even on a diet already adequately supplied with vitamin D. Loss of $\mathrm{Ca}$ through the bowel is accompanied by excessive loss of $\mathrm{Ca}$ soaps at the same time 
(Steudel, 1944). Ca is lost through the bowel in coeliac disease, in idiopathic steatorrhoea (Hunter, I93०a-c) and in sprue. Such Ca loss also occurs if fat of too high a melting-point is used in the manufacture of margarine (Chanda, 1949; Westerlund, 1947; Dutta, 1948). Butter (Steggerda \& Mitchell, r95 I) and margarine of suitable melting-point do not have this effect.

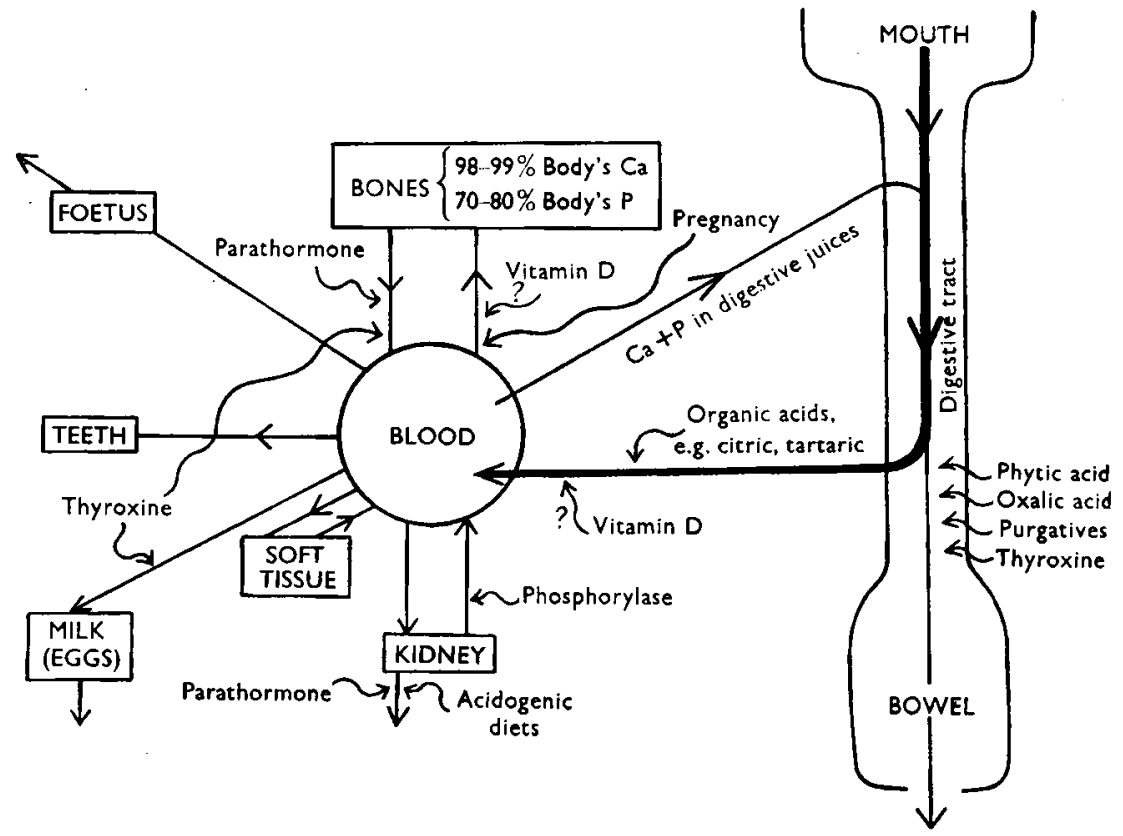

Fig. 3. Diagrammatic representation of metabolism of calcium and phosphorus. The wavy arrows indicate acceleration. No attempt has been made to segregate action upon $\mathrm{Ca}$ from action upon $\mathrm{P}$. Since the composition of bone makes it difficult for either of these elements to be laid down in bone or be withdrawn from bone without the other, the composition of bone salts is generally regarded as constant (Follis, 1952) unless metabolism of bone is seriousiy deranged (Stewart, 1932-3, 1934-5). The diagram is consistent with facts cited by Best $\&$ Taylor (1950) but the interpretations are somewhat different. The present author believes that the maintenance of blood $\mathrm{Ca}$ to prevent tetany takes priority over adequate skeletal mineralization so that rickets results if the intake of $\mathrm{Ca}$ and $P$ is too small.

Ewer \& Bartrum (1948) and Grant (195I) have studied the production of rickets that occurs when young animals are allowed to graze young green oats. It is possible that such young green material contains over $30 \%$ protein (Owen, 1943) in a very digestible form and that its power to produce rickets is thus either generated or aggravated by an excessive stimulation of growth by a diet rich in protein, rich in digestible carbohydrate, poor in calcium and entirely lacking in vitamin D. If this theory is correct such rickets should be of the low-Ca type and should be aggravated by supplementation with $\mathrm{P}$ or prevented by administration of calcium lactate. Grazing animals may be subjected to wide variations in the $\mathrm{Ca}: \mathrm{P}$ ratio of their diets. This ratio will be small in spring-time when the grass is young and large in autumn when it is old, for, as grass ages, it becomes richer in $\mathrm{Ca}$ and poorer in $\mathrm{P}$ (Waite, Holmes, Campbell \& Fergusson, 1950). Feeding of seeds (oats and beans) undoes the effect of this disparity 
by providing $\mathrm{P}$ partly as phytate which is, however, a good source of $\mathrm{P}$ for the ruminant because phytate is digested by the rumen bacteria (Reid, Franklin \& Hallsworth, 1947). Seeds have a ratio of $\mathrm{P}$ to $\mathrm{Ca}$ which offsets the large $\mathrm{Ca}: \mathrm{P}$ ratio of roughage.

\section{SUMMARY}

In conclusion, it may be said that the body's stores of calcium and phosphorus in the bones are labile and can only be filled in the young growing organism if the $\mathrm{Ca}$ and $\mathrm{P}$ in the diet bear a favourable ratio to one another (see Fig. 3). In animals on diets otherwise adequate, but deficient in $\mathrm{Ca}, \mathrm{P}$ or $\mathrm{Mg}$ the soft tissues compete with the bones for $\mathrm{Ca}$ and $\mathrm{P}$ or $\mathrm{Mg}$ so that mineral is lost from the skeleton in adults. In the younger organism an undermineralized skeleton, which may be rickety, is formed. Vitamin D protects the organism by favouring the bones at the expense of the soft tissues. In early lactation the mammary gland draws heavily on the stores of $\mathrm{Ca}$ and $\mathrm{P}$ in the skeleton. The mammary gland thus resembles the other soft tissues, including the foetus and the developing egg. The $\mathrm{Ca}, \mathrm{P}$ and $\mathrm{Mg}$ of the teeth seem to be, at least in part, protected from undue competition with the body's soft tissues. Mineral in the teeth is irreversibly deposited.

\section{REFERENCES}

Adams, M., Boothby, W. M. \& Snell, A. M. (1935-6). Amer. F. Physiol. r14, 383 .

Alwens (1919). Münch. med. Wschr. 66, 1071.

Anderson, I. A. \& Lyall, A. (1939). Quart. Э. Med. (N.S.), 8, 209.

Best, C. H. \& Taylor, N. B. (1950). The Physiological Basis of Medical Practice, 5th ed. Baltimore: Williams and Wilkins Co.

British Medical Association (1950). Report of the Committee on Nutrition. London: British Medical Association.

Chanda, R. (1949). Brit. F. Nutrit. 3, v.

Chanda, R. \& Owen, E. C. (r952). Biochem. F. 50, 100.

Cohn, W. E. \& Greenberg, D. M. (1939). F. biol. Chem. 130, 625.

Conner, R. T., Kao, H.-C. \& Sherman, H. C. (194I). F. biol. Chem. r39, 835 .

Conner, R. T. \& Sherman, H. C. (1936). F. biol. Chem. x15, 695.

Dalyell, E. J. \& Chick, H. (I92I). Lancet, 20r, 842.

Doyle, M. D. \& Porter, T. E. (I95I). F. Nutrit. 45, 29.

Duckworth, J. \& Godden, W. (r940-1). F. Physiol. 99, r.

Duckworth, J. \& Godden, W. (194I). Biochem. F 35, 816.

Duckworth, J. \& Godden, W. (1943). Biochem. F. 37, 595.

Duckworth, J., Godden, W. \& Warnock, G. M. (1940). Biochem. F. 34, 97.

Dutta, N. C. (1948). Ann. Biochem. 8, 137.

Ewer, T. K. \& Bartrum, P. (1948). Aust. vet. F. 24, 73.

Fairbanks, B. W. \& Mitchell, H. H. (1936). F. Nutrit. I1, 551 .

Follis, R. H. (1952). $ๆ$. biol. Chem. 194, 223.

Gaunt, W. E., Griffith, H. D. \& Irving, J. T. (1942). F. Physiol. 1oo, 372.

Gaunt, W. E. \& Irving, J. T. (1939). F. Physiol. 95, 5 I $P$.

Gaunt, W. E. \& Irving, J. T. (1940-1). F. Physiol. 99, 18.

Grant, A. B. (1951). Nature, Lond., 168, 789 .

Grauhan, M. \& Schulz, J. (1939). Med. Klinik. 35, 303.

Harrison, H. E. \& Harrison, H. C. (1951). F. biol. Chem. 188, 83.

Hess, A. F. \& Unger, L. J. (1918). F. Amer. med. Ass. 70, 900.

Hume, E. M. \& Nirenstein, E. (I92I). Lancet, 20r, 849.

Hummel, F. C., Sternberger, H. R., Hunscher, H. A. \& Macy, I. G. (1936). F. Nutrit. I1, 235.

Hunter, D. (1930a). Lancet, 218, 897.

Hunter, D. (r930b). Lancet, 218, 947.

Hunter, D. (r930c). Lancet, 2r8, 999.

Irving, J. T. (1940). F. Physiol. 99, 8.

McCance, R. A. (x949). Brit. F. Nutrit. 2, 401.

Maxwell, J. P. (1935). Chin. med. F. 49, 47. 
Mellanby, E. (1921). Spec. Rep. Ser. med. Res. Coun., Lond., no. 6r.

Mellanby, E. (I925). Spec. Rep. Ser. med. Res. Coun., Lond., no. 93.

Mellanby, E. (1949). F. Physiol. 109, 488.

Meulengracht, E. (1938). Lancet, 235, 774 .

Migicovsky, B. B. \& Emslie, A. R. G. (1949). Arch. Biochem. 20, 325.

Nordfeldt, S. (1949). Kgl. LantbrHögsk. Ann. I6, I I4.

Orr, J. B. \& Clark, M. L. (1930). Lancet, 219, 594.

Owen, E. C. (1943). Unpublished observations.

Owen, E. C. (1948). Biochem. 7. 43, 243.

Owen, E. C., Irving, J. T. \& Lyall, A. (1940). Acta med. scand. ro3, 235.

Park, E. A. (1923). Physiol. Rev. 3, ro6.

Reid, R. L., Franklin, M. C. \& Hallsworth, E. G. (1947). Aust. vet. F. 23, г36.

Rottensten, K. V. (1938). Biochem. F. 32, 1285.

Schmidt-Nielsen, B. \& Schmidt-Nielsen, K. (1944). Nord. Med. 23, 1463.

Shelling, D. H. (1932). F. biol. Chem. 96, 195.

Shepherd, M. L. \& Macy, I. G. (1939). Med. Wom. F. 46, i 7.

Shohl, A. T. (1939). Mineral Metabolism, New York: Reinhold Publishing Corp.

Singsen, E. P. (1948). Bull. Storrs agric. Exp. Sta. no. 260, p. 53.

Skill, D. I. \& Kay, H. D. (1934). Biochem. F. 28 , 2228.

Steggerda, F. R. \& Mitchell, H. H. (1951). F. Nutrit. 45, 201.

Steudel, H. (1944). Ernährung, 9, 37.

Stewart, J. (1932-3). Rep. Inst. Anim. Path. Univ. Camb. no. 3.

Stewart, J. (1934-5). Rep. Inst. Anim. Path. Univ. Camb. no. 4.

Theiler, A. (1919). Fmrs' Weekly, S. Afr., 7 May.

Theiler, A. \& Green, H. H. (1931-2). Nutr. Abstr. Rev. 1, 359.

Tyler, C. (1948-9). Nutr. Abstr. Rev. 18, 473.

Tyler, C. (1949-50). Nutr. Abstr. Rev. 19, 263.

Waite, R., Holmes, W., Campbell, J. I. \& Fergusson, D. L. (1950). F. agric. Sci. 40, 392.

Westerlund, A. (1947). Annals roy. agric. Coll. Sweden, 14, 325.

Zucker, L. M. \& Zucker, T. F. (1946). Amer. F. Physiol. 146, 593.

\section{Bone and Toxic Minerals}

\section{By S. L. TomPSeTt, Biochemical Laboratory, Western General Hospital, Edinburgh}

During the years between the wars, we have seen the development of the spectrograph and of sensitive colorimetric methods for the identification and determination of elements in biological materials. As a result it has been established that animal and human tissues contain elements whose existence in the tissues had not previously been recognized. The concentration of these elements is low in comparison with that of such elements as sodium and potassium. It is quite possible that, if more sensitive methods could be devised, other elements would be recognized in even more minute concentrations.

It is of some interest to consider the reasons stimulating such work. In certain instances it was simply a desire to determine the maximum number of elements, even in low concentration, in animal and human tissues. At the same time our knowledge of the nutritional requirements of the animal body was being extended. During this period it was established that copper was a constant constituent of animal tissues and, although present in low concentration, was an essential element. Increased interest was also being taken in industrial toxicology. It became necessary to develop more sensitive and reliable methods for the identification and determination of toxic elements in excreta and in tissues. 